\title{
Depth profiling of CdS homojunction using AES analysis
}

\author{
K P VARKEY, K P VIJAYAKUMAR*, JUN IMAI'. \\ TOSHIHJRO YOSHIDA ${ }^{\dagger \dagger}$ and YASUBE KASHIWABA ${ }^{\dagger \dagger}$
}

Department of Physics, Cochin University of Science and Technology, Cochin 682022, India ${ }^{+}$Department of Applied Chemistry and Molecular Science, Faculty of Engineering, lwate University, Ueda 4-3-0, Morioka 020, Japan

${ }^{\dagger \dagger}$ Chemical Division, Iwate Industrial Research Institute, Tioka-Shinden, Morioka 020, Japan ${ }^{+t}$ Department of Electrical and Electronic Engineering, Faculty of Engineering, Iwate University, Morioka 020, Japan

MS received 31 July 1997; revised 17 October 1997

\begin{abstract}
Top layer of spray pyrolyzed $n$-type CdS has been converted into $p$-type by diffusion of copper which resulted in the formation of homojunction. This is achieved by annealing $\mathrm{CdS} / \mathrm{Cu}$ bilayer film. The nature of diffusion of copper atoms into CdS has been studied using auger electron spectroscopy (AES).
\end{abstract}

Keywords. Cadmium sulphide; spray pyrolysis; AES.

\section{Introduction}

Cadmium sulphide (CdS) thin films have potential application in optoelectronics. These films can be prepared in large area by simple and low-cost processes viz. spray pyrolysis technique (Chamberlin and Sakarman 1966) and chemical bath deposition technique (Kaur et al 1980). Moreover it forms heterojunctions with a number of materials like $\mathrm{Cu}_{x} \mathrm{~S}$ (Norian and Edigton 1981), CdTe (Arita et al 1991), CuInSe (Schwartz et al 1991) etc. Normally the conductivity of as-prepared CdS thin films will be $n$-type (Chopra and Das 1983). Kashiwaba et al (1992) recently reported the $p$-type characteristics of copper-doped $\mathrm{CdS}$ thin films prepared by vacuum evaporation. Later, Sunny Mathew et al (1995) reported the p-type characteristics of copper-doped CdS thin films deposited using spray pyrolysis technique, and, with the help of techniques like XRD, XPS and optical absorption, they confirmed that compounds like $\mathrm{Cu}_{x} \mathrm{~S}$ have not been formed owing to diffusion of copper atoms into the CdS film.

Keeping the idea of device fabrication, we fabricated a homojunction in spraypyrolized CdS films and the results are reported elsewhere (Varkey and Vijayakumar 1997). We have studied the nature of copper diffusion into CdS film using auger electron spectroscopy (AES) and the results are reported in this paper.

\section{Experimental}

Transparent and conducting $\mathrm{SnO}_{2}$ thin films were prepared by spraying an alcoholic solution of stannic chloride $\left(\mathrm{SnCl}_{4} \cdot 5 \mathrm{H}_{2} \mathrm{O}\right.$ ) over a very clean glass plate kept at $500^{\circ} \mathrm{C}$ with compressed air as the carrier gas. Thickness of $\mathrm{SnO}_{2}$ films coated were $\sim 500 \mathrm{~nm}$ and this was the lower electrode for the device. This layer had an optical transmission of $80 \%$ and a resistivity of $25 \times 10^{-6} \Omega \mathrm{m}$.

\footnotetext{
*Author for correspondence
} 
$\mathrm{CdS}$ thin films were prepared by spray pyrolysis technique on $\mathrm{SnO}_{2}$-coated glass substrate. Solutions of cadmium chloride $(0.02 \mathrm{M})$ and thiourea $(0.02 \mathrm{M})$ were prepared and mixed in the ratio 1:1 by volume. This was sprayed on to the $\mathrm{SnO}_{2}$-coated glass substrate kept at $300^{\circ} \mathrm{C}$. The spray rate was kept at $15 \mathrm{cc}$ per min, which ensured uniform thickness. Thickness of the film was about $1.3 \mu \mathrm{m}$, and the type of conductivity of the CdS film was found to be $n$-type. High pure copper $(99.999 \%)$ was deposited on the as-prepared $n$-CdS film by vacuum evaporation at room temperature in a high vacuum coating unit at a pressure slightly less than $1 \times 10^{-5}$ torr. Thickness of the copper layer was about $400 \mathrm{~nm}$. These samples with the copper layer on top surface were annealed in vacuum $\left(10^{-4}\right.$ torr) at temperatures in the range $100^{\circ} \mathrm{C}-300^{\circ} \mathrm{C}$ for 45 min. The heating and cooling rates were kept at $2^{\circ} \mathrm{C} / \mathrm{min}$ in all the cases.

Due to annealing the copper deposited on top of $n$-CdS diffused into it. Electrical connection to the top layer was given by depositing indium (thickness $\sim 500 \mathrm{~nm}$ ) using vacuum evaporation.

\section{Results and discussions}

AES analysis of a sample annealed at $300^{\circ} \mathrm{C}$ is shown in figure 1 , which shows that thickness of copper layer on the top surface of the annealed sample is very feeble and the copper concentration increases and reaches a maximum value at about a depth of $100 \mathrm{~nm}$ on CdS film and thereafter the concentration of copper decreases rapidly. This result agrees with the earlier VASE analysis in which it was shown that the diffusion of copper into CdS layer is not homogeneous (Sunny Mathew et al 1995). Further, the AES analysis shows that there is a layer of $n$-CdS at the bottom without any trace of copper. This result supports our earlier work of fabricating a homojunction on CdS thin films. From the figure we can see that the depth of free $n$-type CdS layer is about

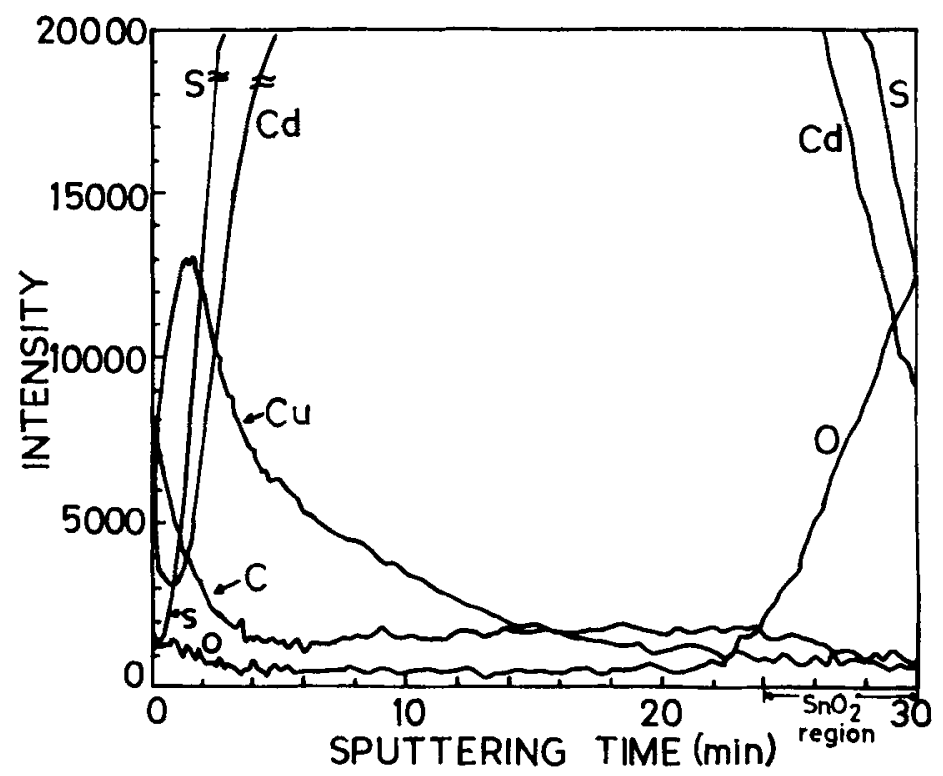

Figure 1. AES depth profile of $p-\mathrm{CdS} / n-\mathrm{CdS} / \mathrm{SnO}_{2}$ sample analysed. 
$500 \mathrm{~nm}$ and the depth of copper diffused p-CdS layer is about $800 \mathrm{~nm}$, since the sputtering rate is $50 \mathrm{~nm} / \mathrm{min}$ for CdS. The percentage of copper atoms diffused is calculated to be $25 \%$. This is in agreement with the earlier work (Kashiwaba et al 1992).

We fabricated a solar cell using this homojunction. Glass coated with conducting transparent layer $\left(\mathrm{SnO}_{2}\right)$ was used as the substrate in this case so that the $\mathrm{SnO}_{2}$ layer will act as the lower electrode of the cell. Evaporated indium over the p-type CdS formed act as the top electrode. Illumination of $60 \mathrm{~mW} / \mathrm{cm}^{2}$ was given through $\mathrm{SnO}_{2}$ side. This gave an open circuit voltage of $200 \mathrm{mV}$ and short circuit current density of $5 \mathrm{~mA} / \mathrm{cm}^{2}$ and the efficiency of the cell is calculated to be $0.73 \%$.

We have done the AES analysis of the homojunction for optimizing $p$-CdS layer and $n$-CdS layer which may improve the efficiency of the cell. Also uniform distribution of copper atoms may increase the cell efficiency. Works are in progress in achieving better efficiency. Even if the efficiency is low, this technique can be used for making a tandem solar cell in which CdS forms top layer over another $p$-type material like CuInSe ${ }_{2}$.

\section{Conclusion}

$\mathrm{CdS} / \mathrm{Cu}$ bilayer has been annealed for diffusing copper into $\mathrm{CdS}$ layer. This resulted in the formation of a p-type CdS at the top layer. Depth profile of copper diffused CdS layer is analysed using AES technique. It is observed that copper atoms have not diffused fully upto the bottom layer of CdS. At the bottom, there remains a layer of $n$-type CdS. This supports the formation of a homojunction.

\section{References}

Arita T, Hanafusa H, Kitamura S and Takakura H 1991 Proc. 22nd IEEE photovoltaic specialist conf. (New York: The Institute of Electrical and Electronics Engineers Inc.) p. 946

Chamberlin R R and Sakarman J S 1966 J. Electrochem. Soc. 11386

Chopra K L and Das S R 1983 Thin film solar cells (New York: Plenum Press) p. 299

Kashiwaba Y, Kanno I and Ikeda T 1992 Jpn J. Appl. Phys. 311170

Kaur I. Pandya D K and Chopra K L 1980 J. Electrochem. Soc. 127943

Norian K H and Edigton J W 1981 Thin Solid Films 7553

Schwartz R J, Gray J L and Lee Y J 1991 Proc. 22nd IEEE photovoltaic specialist conf. (New York: The Institute of Electrical and Electronics Engineers Inc.) p. 920

Sunny Mathew, Mukerjee P S and Vijayakumar K P 1995 Jpn J. Appl. Phys. 344940

Varkey K P and Vijayakumar K P 1997 Jpn J. Appl. Phys. 36 L394 